\title{
Ventricular Pre-excitation Causing Left Ventricular Dysfunction Partially Reverted After Ablation of the Accessory Pathway
}

\author{
Pré-excitação Ventricular como Causa de Disfunção Ventricular Esquerda \\ Parcialmente Reversível com Ablação da via Anômala \\ João Paulo Chaves de Melo1', Maria Licia Ribeiro Cury Pavão1', Elerson Arfelli', Marcelo Garcia Leal', \\ José Antonio Marin-Neto ${ }^{1}$, Andre Schmidt ${ }^{1, *}$
}

ORCID IDS

Melo JPC (D) https://orcid.org/0000-0001-9301-0977

Pavão MLRC (D) https://orcid.org/0000-0002-6963-3776

Arfelli E (D) https://orcid.org/0000-0002-8085-2195

Leal MG (D) https://orcid.org/0000-0002-5458-1782

Marin-Neto JA (D) https://orcid.org/0000-0002-8651-8833

Schmidt A (D) https://orcid.org/0000-0002-1090-8165

\begin{abstract}
Ventricular pre-excitation is one of the rarest causes of cardiomyopathy induced or mediated by arrhythmia. Right accessory pathways, specifically with left bundle branch block pattern, can cause ventricular dysfunction, since abnormal ventricular activation resulting from anterograde atrioventricular conduction can cause atrioventricular, interventricular, and intraventricular dyssynchrony, with asynchronous contraction of the ventricular wall and mitral regurgitation. An asymptomatic patient, with ventricular pre-excitation with left bundle branch block and moderate ventricular dysfunction at echocardiography was described. The electrophysiological study demonstrated an accessory route of anterior location and with an anterograde refractory period of $600 \mathrm{~ms}$, successfully performing radiofrequency ablation and substantial improvement of ventricular function.
\end{abstract}

KEYWORDS: Ventricular dysfunction; Wolff-Parkinson-White syndrome; Catheter ablation.

\section{RESUMO}

A pré-excitação ventricular é causa rara de cardiomiopatia induzida ou mediada por arritmias. As vias acessórias à direita, especificamente com padrão de bloqueio de ramo esquerdo, podem causar disfunção ventricular pela ativação ventricular anormal resultante da condução anterógrada pela via acessória, por causar dessincronismo atrioventricular, interventricular e intraventricular, com contração assíncrona da parede ventricular e regurgitação mitral. Foi descrita uma paciente assintomática, com eletrocardiograma exibindo pré-excitação ventricular, bloqueio do ramo esquerdo e disfunção ventricular sistólica moderada. Estudo eletrofisiológico demonstrou via acessória de localização anterior e com período refratário anterógrado de 600 ms, realizando-se ablação por radiofrequência com sucesso e significativa melhora da função ventricular.

PALAVRAS-CHAVE: Disfunção ventricular; Síndrome de préexcitação; Ablação por cateter.

1. Universidade de São Paulo - Faculdade de Medicina de Ribeirão Preto - Hospital das Clínicas - Ribeirão Preto (SP) - Brazil. *Correspondence author: aschmidt@fmrp.usp.br Received: 08 Nov 2019 | Accepted: 19 Nov 2019 Section Editor: J. Tarcísio Medeiros de Vasconcelos 


\section{INTRODUCTION}

Anomalous accessory pathways are remnants tissues resulting from incomplete embryological development of the atrioventricular (AV) ring and failure of fibrous separation between the atria and ventricles. In ventricular pre-excitation syndrome, also known as Wolff-ParkinsonWhite syndrome, AV conduction occurs, partially or totally, through the accessory pathway, which results in earlier activation (pre-excitation) of the ventricles ${ }^{1}$. It is a relatively common anomaly, with an estimated 1-3/1000 live births ${ }^{1}$. It may be asymptomatic, manifest as paroxysmal supraventricular tachycardia (PSVT), or, although more rarely, present as syncope or sudden death due to the rapid conduct of an atrial tachyarrhythmia by the accessory route ${ }^{2}$. Although occasional episodes of PSVT are generally not associated with the development of ventricular dysfunction, there is a possibility in cases of incessant tachycardia. Additionally, abnormal ventricular activation resulting from early anterograde conduction may cause atrioventricular, interventricular, and intraventricular desynchrony and also result in cardiomyopathy ${ }^{3}$.

In this case report, a patient with pre-excitation of the right ventricle and depressed left ventricular function is presented, in which successful ablation of the accessory pathway resulted in substantial improvement of the left ventricular ejection fraction (LVEF).

\section{CASE REPORT}

D.A.B., 39 years old, female, carrier of human immunodeficiency syndrome and hepatitis $\mathrm{C}$, in outpatient follow-up, maintaining the undetectable viral load. Asymptomatic from the cardiovascular point of view, she started pre-treatment evaluation for hepatitis $\mathrm{C}$, and a short PR interval and typical delta wave were identified on electrocardiogram (ECG). The ECG suggested a pattern of left bundle branch block (LBBB) compatible with an accessory pathway localization in the tricuspid ring (Fig. 1). Transthoracic echocardiography, performed in January 2016, revealed left ventricular (LV) dilatation, with a telediastolic diameter (TDD) of $58 \mathrm{~mm}$ and moderate left ventricular dysfunction (LVD 36\%). There was no family history of cardiomyopathy, no viral disease in the recent past, and coronary artery disease was also excluded by myocardial perfusion scintigraphy during exercises and rest.

Risk stratification associated with the accessory pathway was performed with 24-hour Holter showing pre-excitation during the entire recording and exercise test, without sudden loss of the ventricular pre-excitation pattern. Next, an electrophysiological study was performed (June 2016), which showed AH interval: $28 \mathrm{~ms}$ and HV interval: $4 \mathrm{~ms}$, with an accessory pathway with anterograde and retrograde conduction properties and with an anterograde effective refractory period of $600 \mathrm{~ms}$, suggesting low risk for severe arrhythmic cardiac events. During endocardial mapping, AV fusion was observed in the anterior region of the tricuspid ring, and radiofrequency pulses that led to the disappearance of the anterograde and retrograde conduits by the accessory pathway were applied. The echocardiogram was repeated in September 2016, which showed a clear improvement in LVEF (46\%),TDD: $52 \mathrm{~mm}$, and also ECG without evidence of ventricular pre-excitation (Fig. 2). In parallel, treatment

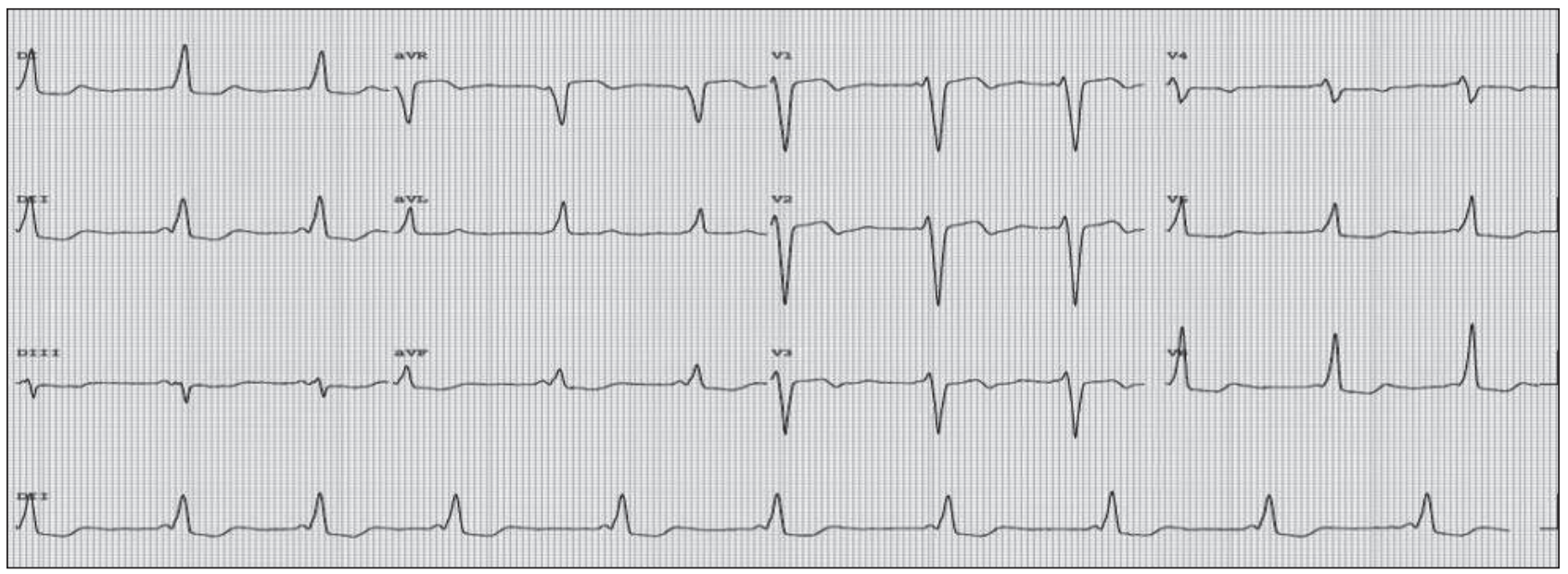

Figure 1. 12-lead electrocardiogram pre-ablation. 


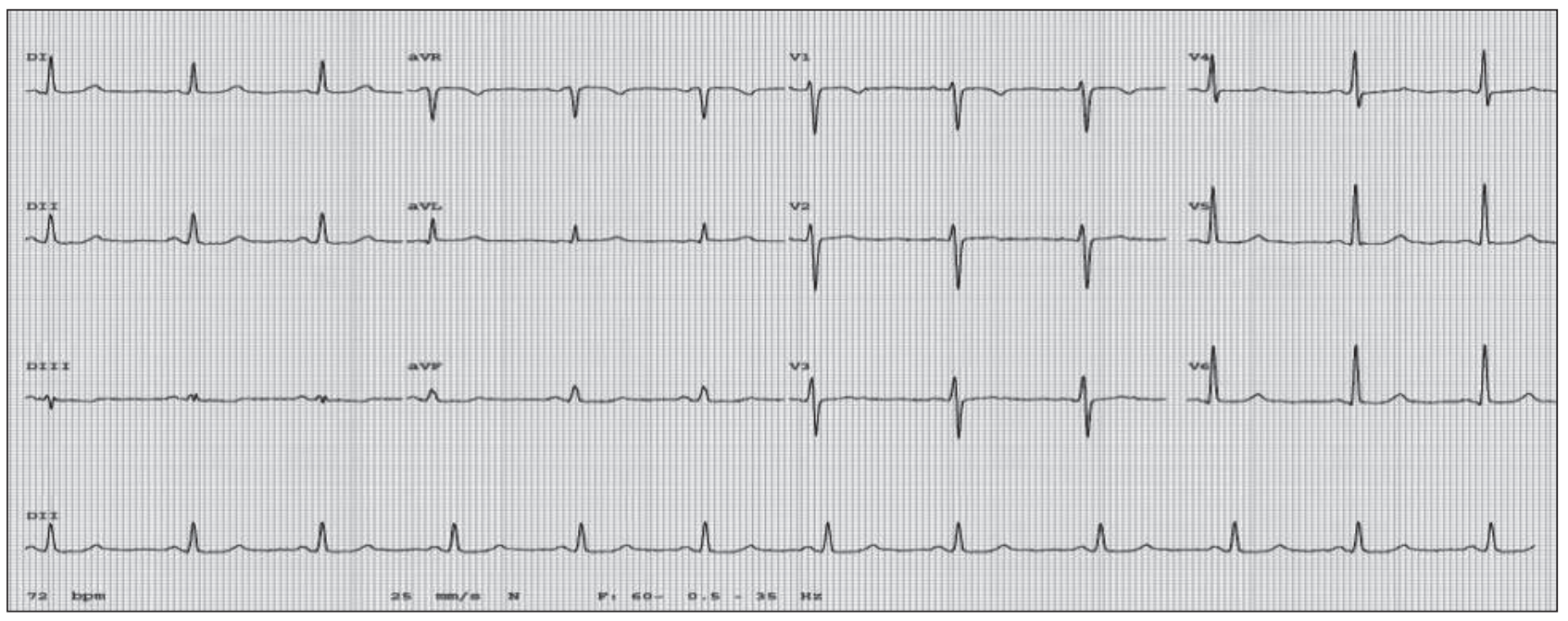

Figure 2. 12-lead electrocardiogram after ablation.

with sofosbuvir and daclatasvir was started in February 2017 for 12 weeks with a negative viral load.

She is currently asymptomatic in outpatient follow-up, with stable systolic ventricular function at the lower limit of normality, in extremely irregular use of beta-blocker (carvedilol), an inhibitor of the angiotensin-converting enzyme - medications she started after ablation.

\section{DISCUSSION}

In this case report, it can be plausibly concluded that the ablation of the accessory pathway was able to practically reverse secondary cardiomyopathy induced by ventricular desynchronism to the accessory pathway of the LBBB pattern.

It is known that $\mathrm{LBBB}$ causes asynchronous movement of the ventricular wall, with potential to evolve to ventricular dysfunction and mitral regurgitation ${ }^{4}$, and it was demonstrated that in patients without another evident cause of ventricular systolic dysfunction, the effective "elimination" of the LBBB pattern and resulting intraventricular desynchrony is the basis for the functional improvement of the $\mathrm{LV}^{5}$. Reinforcing the role of desynchrony in the pathogenesis of heart failure (HF), several studies evaluated the clinical impact of cardiac resynchronization therapy in the reversal of ventricular dysfunction ${ }^{6,7}$.

Also, it has become widely accepted, based on relatively recent clinical trials, that long-term right ventricular (RV) stimulation promotes the progression of heart failure due to the deterioration of $\mathrm{LV}$ function. Again, it seems likely that RV stimulation results in a scenario essentially equivalent to ventricular desynchronism induced by LBBB, with an adverse effect on LV structure and functionality ${ }^{8}$.

Finally, there are several reports in the literature describing patients with frequent ventricular extrasystoles (VES) (> 20\%) originating from the RV ejection pathway, with LV dilatation and LVEF reduction. Successful catheter ablation reversed LV dilation and dysfunction. It is presumed that the VES that manifests the LBBB morphology originated desynchrony and LV dysfunction?

In the case of ventricular pre-excitation, ventricular dysfunction in the absence of sustained tachycardia is less common, with only isolated case reports. Most of the reported cases related to ventricular desynchronism were associated with the right posteroseptal accessory pathway. However, the right anterior and right lateral accessory pathways and the fasciculoventricular pathways were also implicated ${ }^{10}$. The treatment with radiofrequency ablation reverses ventricular dysfunction in most cases because it eliminates ventricular desynchrony ${ }^{11}$.

\section{CONCLUSION}

Given the previous reports on the potential impact of the LBBB-type activation pattern on desynchrony and ventricular function, as well as the exclusion of more common causes of ventricular dysfunction, it is plausible to admit that the right ventricle pre-excitation has caused 
reversible dilatation and left ventricular dysfunction. Thus, in patients with a tricuspid ring accessory pathway and depressed heart function, catheter ablation to eliminate pre-excitation may have beneficial effects on heart function, in addition to eliminating its susceptibility to recurrent tachyarrhythmias.

\section{AUTHORS' CONTRIBUTION}

\author{
Conceptualization,MeloJPC and Pavão MLR;Methodology,
} MeloJPC; Investigation, Arfelli E,Pavão MLRC, and Leal MG; Writing - Original Draft, Melo JPC; Writing - Review and Editing,Schmidt A and Marin-Neto JA; Supervision, Schmidt A.

\section{REFERENCES}

1. Cohen MI, Triedman JK, Cannon BC, Davis AM, Drago F, Janousek J, et al. PACES/HRS Expert Consensus Statement on the Management of the Asymptomatic Young Patient with a Wolff-Parkinson-White (WPW, Ventricular Preexcitation) Electrocardiographic Pattern: Developed in partnership between the Pediatric and Congenital Electrophysiology Society (PACES) and the Heart Rhythm Society (HRS). Endorsed by the governing bodies of PACES, HRS, the American College of Cardiology Foundation (ACCF), the American Heart Association (AHA), the American Academy of Pediatrics (AAP), and the Canadian Heart Rhythm Society (CHRS). Heart Rhythm. 2012;9:1006-24. https://doi. org/10.1016/j.hrthm.2012.03.050

2. Kohli U, Pumphrey $\mathrm{KL}$, Ahmed A, Das S. Pre-excitation induced ventricular dysfunction and successful berlin heart explantation after accessory pathway ablation. J Electrocardiol. 2018;51(6):1067-70. https://doi.org/10.1016/j. jelectrocard.2018.09.008

3. Shan Q, Jin Y, Cao K. Reversible left ventricular dyssynchrony and dysfunction resulting from right ventricular preexcitation. EP Europace. 2007;9(8):697-701. https://doi. org/10.1093/europace/eum138

4. Bradley DJ, Bradley EA, Baughman KL, Berger RD, Calkins $\mathrm{H}$, Goodman SN, et al. Cardiac resynchronization and death from progressive heart failure: a meta-analysis of randomized controlled trials. JAMA. 2003;289(6):730-40. https://doi.org/10.1001/jama.289.6.730

5. Blanc J, Fatemi M, Bertault V, Baraket F, Etienne Y. Evaluation of left bundle branch block as a reversible cause of nonischaemic dilated cardiomyopathy with severe heart failure. A new concept of left ventricular dyssynchrony-induced cardiomyopathy. EP Europace. 2005;7(6):604-10. https:// doi.org/10.1016/j.eupc.2005.06.005
6. William TA, David LH. Cardiac resynchronization therapy for heart failure. Circulation. 2003;108(21):2596-603. https:// doi.org/10.1161/01.CIR.0000096580.26969.9A

7. William TA, Fisher WG, Smith AL, Delurgio DB, Leon AR, Loh $E$, et al. Cardiac resynchronization in chronic heart failure. N Engl J Med. 2002;346(24):1845-53. https://doi.org/10.1056/ NEJMoa013168

8. Tops LF, Schalij MJ, Holman ER, Van Erven L, Van Der Wall EE, Bax J. Right ventricular pacing can induce ventricular dyssynchrony in patients with atrial fibrillation after atrioventricular node ablation. J Am Coll Cardiol. 2006;48(8):1642-8. https://doi.org/10.1016/j. jacc.2006.05.072

9. Takemoto M, Yoshimura H, Ohba Y, Matsumoto Y, Yamamoto $U$, Mohri $M$, et al. Radiofrequency catheter ablation of premature ventricular complexes from right ventricular outflow tract improves left ventricular dilation and clinical status in patients without structural heart disease. J Am Coll Cardiol. 2005;45(8):1259-1265. https://doi.org/10.1016/j. jacc.2004.12.073

10. Tomaske M, Janousek J, Razek V, Gebauer RA, Tomek V, Hindricks $G$, et al. Adverse effects of Wolff-Parkinson-White syndrome with right septal or posteroseptal accessory pathways on cardiac function. EP Europace. 2008;10(2):181189. https://doi.org/10.1093/europace/eun005

11. Guo B, Dai C, Li Q, Li W, Han L. Hazards of ventricular pre-excitation to left ventricular systolic function and ventricular wall motion in children: analysis of 25 cases. Cardiol Young. 2019;29(3):380-388. https://doi.org/10.1017/ S1047951118002500 